\title{
Distinct Modes of Dopamine and GABA Release in a Dual Transmitter Neuron
}

\author{
Maria Borisovska, AeSoon L. Bensen, Gene Chong, and Gary L. Westbrook \\ Vollum Institute, Oregon Health and Science University, Portland, Oregon 97239
}

We now know of a surprising number of cases where single neurons contain multiple neurotransmitters. Neurons that contain a fastacting neurotransmitter, such as glutamate or GABA, and a modulatory transmitter, such as dopamine, are a particularly interesting case because they presumably serve dual signaling functions. The olfactory bulb contains a large population of GABA- and dopaminecontaining neurons that have been implicated in normal olfaction as well as in Parkinson's disease. Yet, they have been classified as nonexocytotic catecholamine neurons because of the apparent lack of vesicular monoamine transporters. Thus, we examined how dopamine is stored and released from tyrosine hydroxylase-positive GFP (TH ${ }^{+}$-GFP) mouse periglomerular neurons in vitro. $\mathrm{TH}^{+}$cells expressed both VMAT2 (vesicular monoamine transporter 2) and VGAT (vesicular GABA transporter), consistent with vesicular storage of both dopamine and GABA. Carbon fiber amperometry revealed that release of dopamine was quantal and calcium-dependent, but quantal size was much less than expected for large dense core vesicles, suggesting that release originated from small clear vesicles identified by electron microscopy. A single action potential in a $\mathrm{TH}^{+}$neuron evoked a brief GABA-mediated synaptic current, whereas evoked dopamine release was asynchronous, lasting for tens of seconds. Our data suggest that dopamine and GABA serve temporally distinct roles in these dual transmitter neurons.

\section{Introduction}

Tyrosine hydroxylase (TH), the first enzyme in catecholamine synthesis, is expressed in a subset of periglomerular neurons (Halász et al., 1977; Parrish-Aungst et al., 2007) that also express GABAergic markers (Kiyokage et al., 2010). $\mathrm{TH}^{+}$periglomerular cells have been classified as nonexocytotic catecholaminergic neurons because the vesicular monoamine transporter (VMAT) could not be detected (Peter et al. 1995; Weihe et al. 2006), although dopamine is present in the glomerular layer (Dahlström and Fuxe, 1964; Coopersmith et al., 1991). Little is known about dopamine release from these putative dual transmitter neurons, but they are well positioned to influence multiple cells in the glomerular microcircuit, including mitral/tufted cells, olfactory afferent nerve terminals, and periglomerular cells (AroniadouAnderjaska et al., 2000; Toida et al., 2000; Smith and Jahr, 2002; Murphy et al., 2005). The application of exogenous dopamine (Hsia et al., 1999; Ennis et al., 2001) or block of dopamine uptake (Maher and Westbrook, 2008) causes D2 receptor-mediated presynaptic inhibition. Likewise, D1 receptors are present on principal neurons in the bulb (Coronas et al., 1997). On a functional

\footnotetext{
Received Sept. 11, 2012; revised Nov. 6, 2012; accepted Nov. 25, 2012.

Author contributions: M.B. and G.L.W. designed research; M.B., A.L.B., and G.C. performed research; M.B. and G.C. analyzed data; M.B. and G.L.W. wrote the paper.

This work was supported by NIH Grant NS26494 (G.L.W.), a Tartar Trust Fellowship (M.B.), and the Neuroscience Imaging Center at Oregon Health and Science University (NIH Grant P30 NSO61800). We thank Wolf Almers for useful discussions, John Williams for reading an early version of the manuscript, Robert Kayton for assistance with electron microscopy, and Mandy Boyd for assistance with cell sorting.

The authors declare no competing interests.

Correspondence should be addressed to Dr. Maria Borisovska, Oregon Health and Science University, 3181 Southwest Sam Jackson Park Road, Portland, OR 97239. E-mail: maria.borisovska@gmail.com.

DOI:10.1523/JNEUROSCI.4342-12.2013

Copyright $\odot 2013$ the authors $\quad 0270-6474 / 13 / 331790-07 \$ 15.00 / 0$
}

level, mice lacking dopamine receptors or transporters have olfactory deficits (Tillerson et al., 2006; Taylor et al., 2009), and loss of smell is an early symptom in Parkinson's disease (Doty, 2012).

The classic view for dopamine release was that of volume transmission in which released dopamine diffuses to receptors in the extrasynaptic membrane (Cragg et al., 2001), whereas monoamine release in chromaffin cells is known to be vesicular (Leszczyszyn et al., 1990; Wightman et al., 1991). More recent studies have detected vesicular release in central dopamine neurons (Jaffe et al., 1998; Pothos et al. 1998; Puopolo et al., 2001). Vesicular release creates brief and local dopamine transients that are required for postsynaptic dopamine IPSCs, at least in the ventral tegmental area (Ford et al., 2009). Interestingly, central dopamine neurons can also contain a classic fast neurotransmitter (Hnasko and Edwards, 2012) and, like periglomerular cells, may release transmitters from dendrites as well as axon terminals (Pinching and Powell, 1971; Kiyokage et al., 2010). How one rationalizes these seemingly opposing views of dopamine signaling in neurons that also release a fast-acting neurotransmitter remains an enigma. $\mathrm{TH}^{+}$periglomerular cells in the olfactory bulb provide a unique system to compare the spatiotemporal profile of monoamine and amino acid secretion. Here, we used TH-GFP mice to examine dopamine and GABA release from periglomerular neurons using amperometry, whole-cell recording, electron microscopy, and real-time PCR.

\section{Materials and Methods}

Dissociated cell cultures. C57BL/6 mice (postnatal days 21-28) that expressed GFP driven by the tyrosine hydroxylase promoter were used to prepare cell cultures (Sawamoto et al. 2001). Both female and male mice were included in the analysis. Horizontal slices of the main olfactory bulb $(500 \mu \mathrm{m})$ were cut using a Leica Biosystems VT1200 S Vibratome. The 
ice-cold oxygenated cutting solution contained (in mM): $83 \mathrm{NaCl}, 26.2$ $\mathrm{NaHO}_{3}, 2.5 \mathrm{KCl}, 1 \mathrm{NaH}_{2} \mathrm{PO}_{4}, 3.3 \mathrm{MgCl}_{2}, 0.5 \mathrm{CaCl}_{2}, 22$ glucose, 72 sucrose, and $0.1 \mathrm{U} / \mathrm{ml}$ of penicillin/streptomycin (Invitrogen), $\mathrm{pH}$ 7.3. For cell cultures, solutions and media were prepared as described previously (Tovar et al., 2009). The glomerular cell layer containing $\mathrm{TH}^{+}$periglomerular cells was microdissected, transferred to the papain-containing solution, and incubated at $37^{\circ} \mathrm{C}$ for $20 \mathrm{~min}$ on a platform nutator. Enzyme solution was than replaced with inactivating solution. Papain was inactivated for $3 \mathrm{~min}$, and the solution was replaced with complete medium. Tissue was dissociated using fire-polished pipettes. Cells were plated on poly-L-lysine-coated coverslips. For microisland cultures, cells were plated on glial microislands (Tovar et al., 2009) with glia obtained from olfactory bulbs of newborn mice. Cells in culture were incubated at $37^{\circ} \mathrm{C}$ and $5 \% \mathrm{CO}_{2}$ and used on days 1 and $7-10$. Cells on microislands were used on days 14-19. The animal protocols were approved by the Institutional Animal Care and Use Committee and followed the National Institutes of Health Guidelines for the Ethical Treatment of Animals.

Cell sorting and real-time PCR. Cell suspensions were obtained as for cell culture. RNase inhibitor ( $200 \mathrm{U} / 5 \mathrm{ml}$ media) was added to the cell suspension before fluorescent-activated cell sorting (FACS). The flow cytometer (FACS Vantage Diva, BD Biosciences) had a $488 \mathrm{~nm}, 200 \mathrm{~mW}$ argon ion laser equipped with a 530/30 nm bandpass filter for EGFP and was operated with the following settings: $10 \mathrm{psi}, 20,000 \mathrm{drops} / \mathrm{s}, 130 \mu \mathrm{m}$ tip. Cells collected from the cell sorter were used to isolate RNA, generate cDNA, and perform quantitative PCR. RNA was isolated from sorted cells using TRIzol (Invitrogen) and the manufacturers' recommended procedures. The samples were DNase treated using the DNA-free kit (Ambion) followed by an additional ethanol precipitation. cDNAs were generated from $200 \mathrm{ng}$ of RNA using random hexamer primers of the First Strand cDNA Synthesis Kit (Fermentas). One sample was serially diluted to provide a standard curve, and all other samples were diluted 1:3. The real time reaction was performed in duplicates using FastStart SYBR Green Master (Roche) with 500 ng of input RNA. PCR was performed on an Opticon OP346 (MJ Research). Primers (forward and reverse): tyrosine hydroxylase, AGGAGAGGGATGGAAATGCT and AACACTTTCAAAGCCCGAGA; dopamine transporter (DAT), CT GACCAACTCCACCCTCAT and CACAGGTAGGGAAACCTCCA; dopamine $\beta$-hydroxylase, GACCCCGAAGGGATTTTAGA and GCAT GATGAGATCTGCGTTC; norepinephrine transporter (NET), AGGC ACCTCCATTCTGTTTG and TAGGTGAGCGGCTTGAAGTT; vesicular monoamine transporter 1 (VMAT1), TGCAATTCTGAACCAGG AATGCCC and ATCGCTGTTCTCTCCCAGTGGAAA; vesicular monoamine transporter (VMAT2), TTACGACCTTGCTGAAGGACCCAT and ATAAGAGATGCTCGCTGGCAGGAA; vesicular GABA transporter (VGAT), ACCAAGAGCCAGACTGTCGT and GACTTGTTGG ACACGGAGGT.

Amperometry and electrophysiology. Carbon fiber electrodes were fabricated as described (Bruns, 2004). Carbon fibers (5 $\mu \mathrm{m}$ diameter) were insulated using electrophoretic deposition of paint to reduce root mean square (RMS) noise. Only carbon fiber electrodes with RMS noise $<2 \mathrm{pA}$ ( $5 \mathrm{kHz}, 4$-pole Butterworth filter) were used for experiments. Carbon fibers were freshly cut before each recording; only cuts that produced a flat surface of the fiber were used for amperometry. The charge associated with an amperometric spike is proportional to the number of catecholamine molecules oxidized on its surface, with each oxidized dopamine molecule producing two electrons. Amperometric currents were recorded with Multiclamp 700B amplifier (Molecular Devices), filtered at 4 $\mathrm{kHz}$ (eight-pole Bessel), and digitized gap free $(20-50 \mathrm{kHz})$. The holding voltage was $+700 \mathrm{mV}$, and amplifier gain was $20 \mathrm{mV} / \mathrm{pA}$. AxoGraph $\mathrm{X}$ (AxoGraph) was used for data collection. All recordings were done at room temperature in Ringer's solution containing (in $\mathrm{mM}$ ): $130 \mathrm{NaCl}, 4$ $\mathrm{KCl}, 1 \mathrm{CaCl}_{2}, 1 \mathrm{MgCl}_{2}, 10$ HEPES, 30 Glucose, $\mathrm{pH}$ 7.3, with NaOH. For microisland cultures, the external $\mathrm{Ca}^{2+}$ was increased to $2 \mathrm{~mm}$. Cells were patched under visual control using differential interference contrast optics and an ORCA II camera (Hamamatsu). Patch pipettes (4-6 M $\Omega$ ) contained (in mM): 110 Cs-gluconate, 20 DPTA, $5 \mathrm{CaCl}_{2}, 2 \mathrm{MgATP}, 0.5$ $\mathrm{Na}_{2}$ GTP, 40 HEPES, pH 7.3, and $\sim 20 \mu \mathrm{M}$ free $\mathrm{Ca}^{2+}$. For whole-cell experiments, the holding membrane potential was set to $-70 \mathrm{mV}$. Recordings of microisland cultured neurons were done using an internal solution containing (in mM): $135 \mathrm{KCl}, 1$ EGTA, $2 \mathrm{MgATP}, 0.5 \mathrm{Na}_{2} \mathrm{GTP}$, 12 HEPES, pH 7.3. To preincubate cells with L-DOPA, fresh $20 \mathrm{~mm}$ L-DOPA stock was added to the cell medium $(100 \mu \mathrm{M}$ final concentration) for $1 \mathrm{~h}$. Reserpine ( $1 \mu \mathrm{M}$ final concentration) was added for $1 \mathrm{~h}$ after $1 \mathrm{~h}$ of L-DOPA incubation, resulting in $2 \mathrm{~h} \mathrm{~L}-\mathrm{DOPA}$ and $1 \mathrm{~h}$ of reserpine incubation. Cells were recorded at $0-2 \mathrm{~h}$ after incubation. L-DOPA and reserpine were purchased from Sigma-Aldrich. SR95531 was purchased from Ascent Scientific.

Electron microscopy. A small grid $(2 \times 2 \mathrm{~mm})$ was printed on Aclar film (Masurovsky and Bunge, 1968). Cells were plated on the opposite side of the print. Neurons at 7 days in culture (DIC) were used because at this age the presence of dendrites facilitated the identification of TH-GFPexpressing cells. Neurons were imaged using a LSM 710 confocal microscope (Zeiss) and $20 \times$ objective. A simultaneous Brightfield and fluorescence images tiled the surface of the grid to allow identification of a well isolated $\mathrm{TH}^{+}$cell and its location. Cells were then fixed with 3\% glutaraldehyde and $2 \%$ paraformaldehyde in $0.1 \mathrm{M}$ cacodylate buffer, $\mathrm{pH}$ 7.4, osmicated with $2 \% \mathrm{OsO}_{4}$ in $0.1 \mathrm{M}$ cacodylate buffer, $\mathrm{pH} 7.4$, for $1 \mathrm{~h}$ at $4^{\circ} \mathrm{C}$ and serially dehydrated in ethanol followed by infiltration with LX112 resin (Ladd Research Industries; polymerization at $60^{\circ} \mathrm{C}$ for $48 \mathrm{~h},<$ $2 \mathrm{~mm}$ thick). Embedded cells were reimaged to verify the location of each $\mathrm{TH}^{+}$neuron. Blocks containing one or a few $\mathrm{TH}^{+}$neurons were cut out and sectioned. Ultrathin sections ( $60 \mathrm{~nm}$, gray/silver interference color) were analyzed with a FEI Tecnai 12 BioTwin Transmission electron microscope. The morphometric analyses were performed on two cultures from two $\mathrm{TH}^{+}$animals. Images acquired with an AMT Active Vu-M 16 megapixel camera (Advanced Microscopy Techniques) were analyzed with ImageJ software (NIH). Large dense core vesicles (LDCVs) were identified by the presence of a dense core inside vesicles. The vesicle diameter $(d)$ was calculated from micrographs (magnification $\times 30,000$ ) by circling each vesicle and determining the perimeter where $d=$ perimeter $/ \pi$. Vesicle diameter was corrected as described previously (Parsons et al., 1995). Electron micrographs of mouse chromaffin cells were prepared as described previously (Borisovska et al., 2005).

Immunohistochemistry and in vivo confocal imaging. Immunocytochemistry and imaging of slices and cultured cells was performed using standard methods (Hannah et al., 1998; Borisovska et al., 2011). VGAT polyclonal antibody was obtained from Synaptic Systems and used at a dilution of 1:500. Images were obtained using a LSM 710 confocal microscope (Zeiss) and $20-63 \times$ objectives as appropriate. To visualize dopamine-containing vesicles in intact slices $(300 \mu \mathrm{m})$ of the olfactory bulb, we preincubated slices with a fluorescent analog of dopamine (Neurotransmitter Transporter Uptake Assay Kit, Molecular Devices) for $60-120 \mathrm{~min}$. The dye was diluted 1:10 from the stock preparation. The excitation wavelength was $457 \mathrm{~nm}$, and confocal images were acquired from horizontal sections of the glomerular cell layer at 8-bit resolution.

Analysis. Amperometric and whole-cell recording data were exported from AxoGraph into Igor Pro using the NeuroMatic routine (Jason Rothman, http://www.neuromatic.thinkrandom.com). Custom Igor Pro routines written by M.B. were used for all analyses. For analysis of amperometric spike frequency before and after stimulation, recordings with up to 1.9 pA RMS noise and at least 20 spikes per recording were included. For spike charge analysis-only recordings with RMS noise, $<1.4 \mathrm{pA}$ were included. The automatic spike detection routine was used and manually verified. Traces were filtered using five binomial smoothing operations. The threshold was set at $4 \mathrm{pA}$ (sliding average $=3$ ). Artifacts caused by whole-cell stimulation were deleted before automatic spike detection. GABA-mediated IPSC amplitudes were determined as the peak current after stimulation. The cumulative probability for GABA-mediated IPSCs was calculated as the average of 10 integrals obtained from each sweep and normalized to $100 \%$. The cumulative probability of amperometric spikes was calculated from spike frequency, normalized to $100 \%$, and averaged over 10 sweeps.

Statistics. Student's $t$ test or ANOVA was used as appropriate. Sample size was based on the number of cells that were pooled from multiple culture preparations and coverslips to minimize bias. Significance is displayed as ${ }^{\star} p \leq 0.05,{ }^{* *} p \leq 0.01$, and ${ }^{* *} p \leq 0.001$. Data are expressed as the mean \pm SEM. 


\section{Results}

Vesicular dopamine release from $\mathrm{TH}^{+}$ periglomerular cells

We used periglomerular neurons from juvenile mice (postnatal days 21-28) that express GFP driven by the tyrosine hydroxylase promoter (Sawamoto et al., 2001). At this age there are abundant $\mathrm{TH}^{+}$neurons in the glomerular layer (Fig. 1A) that nearly completely overlap with $\mathrm{TH}$ immunoreactivity (Maher and Westbrook, 2008). To examine monoamine release from $\mathrm{TH}^{+}$periglomerular neurons, we fabricated low-noise carbon fiber electrodes that detect release of oxidizable neurotransmitters like dopamine on the time scale of microseconds (Wightman et al., 1991). Calibration of the carbon fibers with exogenous dopamine indicated a linear response from 3 $\mu \mathrm{M}$ to $5 \mathrm{~mm}$ (Fig. $1 B$ ). Detection of single vesicles with amperometry requires close contact with the cell membrane, and thus we used cultured $\mathrm{TH}^{+}$cells that were easily identified in vitro and developed neurites after a few days (Fig. 1A). Positioning of the carbon fiber electrode in direct contact with the cell membrane of a $\mathrm{TH}^{+}$cell after 1 DIC revealed a low rate of spontaneous amperometric spikes $(0.04 \pm 0.01$ $\mathrm{Hz}, n=8$ ), consistent with the release of endogenous dopamine. To maximize the detection of events by amperometry and to ensure that $\mathrm{Ca}^{2+}{ }_{i}$ reached all submembrane regions, we used whole-cell pipettes containing $20 \mu \mathrm{M}$ free $\mathrm{Ca}^{2+}$ to quickly increase intracellular calcium. Intracellular dialysis with a whole-cell pipette containing $20 \mu \mathrm{M}$ free $\mathrm{Ca}^{2+}$ caused a 20 -fold increase in spike frequency $(0.8 \pm 0.2 \mathrm{~Hz}$, $n=8, p=0.001$ paired $t$ test, Fig. $1 C$ ). Plots of the cumulative spike frequency (Fig. 1C, lower traces) showed a steady low rate of activity in the absence of calcium stimulation, which then increased throughout the $100 \mathrm{~s}$ exposure to increased intracellular calcium. At 7 DIC, spontaneous spikes also were easily detectable in $\mathrm{TH}^{+}$cells after preincubation with L-DOPA to increase intracellular dopamine and the sensitivity of amperometry $(100 \mu \mathrm{M}, 1 \mathrm{~h}$, Fig. $1 C$; Pothos et al., 1996). The rate of release was further increased following whole-cell calcium perfusion (spontaneous $0.6 \pm 0.2 \mathrm{~Hz}$; evoked $2.2 \pm 0.5 \mathrm{~Hz}, n=7$, $p=0.015$, paired $t$ test) and showed a similar calcium-stimulated increase in cumulative spike frequency. Increasing the $\mathrm{Ca}_{\mathrm{i}}{ }^{2+}$ to $50 \mu \mathrm{M}$ or external application of the calcium ionophore ionomycin did not further increase the frequency of spikes (data not shown). There were no detectable amperometric spikes in $\mathrm{TH}-$ negative periglomerular cells with or without L-DOPA $(n=8$, Fig. $1 C$ ), indicating that the release was specific to $\mathrm{TH}^{+}$cells.

$100 \%$

8DIC $\mathrm{TH}^{-}+\mathrm{L}-\mathrm{DOPA}$
B
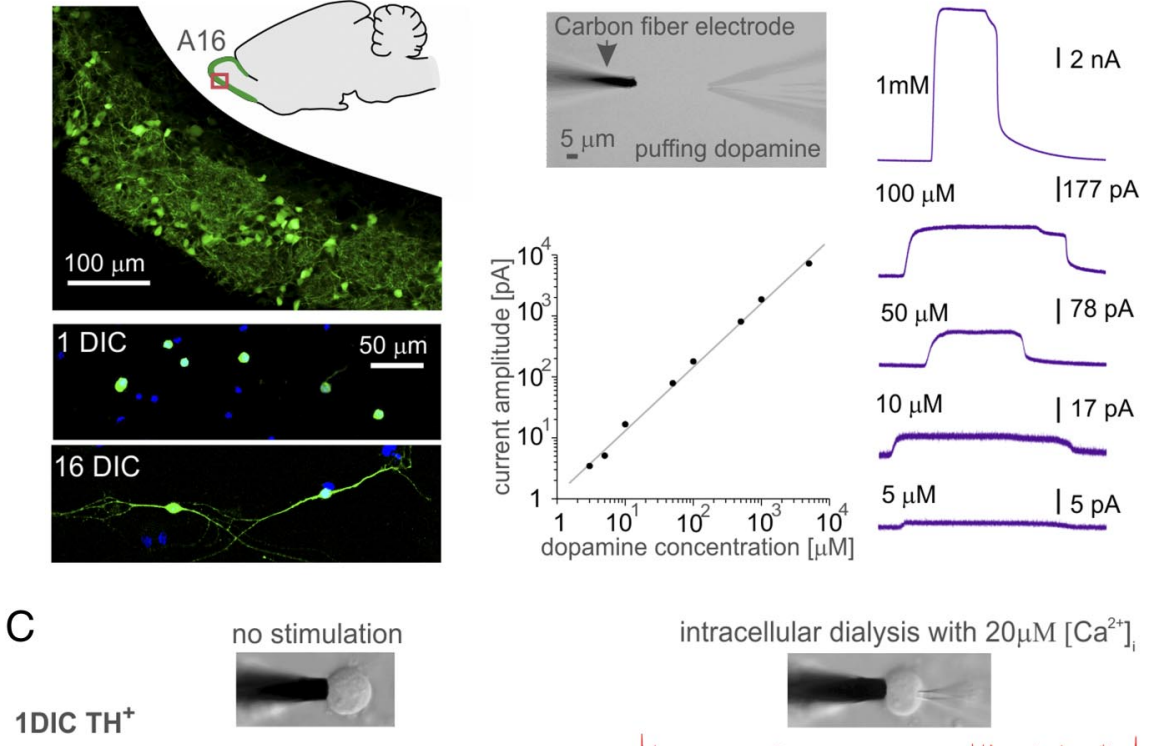

intracellular dialysis with $20 \mu \mathrm{M}\left[\mathrm{Ca}^{2+}\right]_{i}$
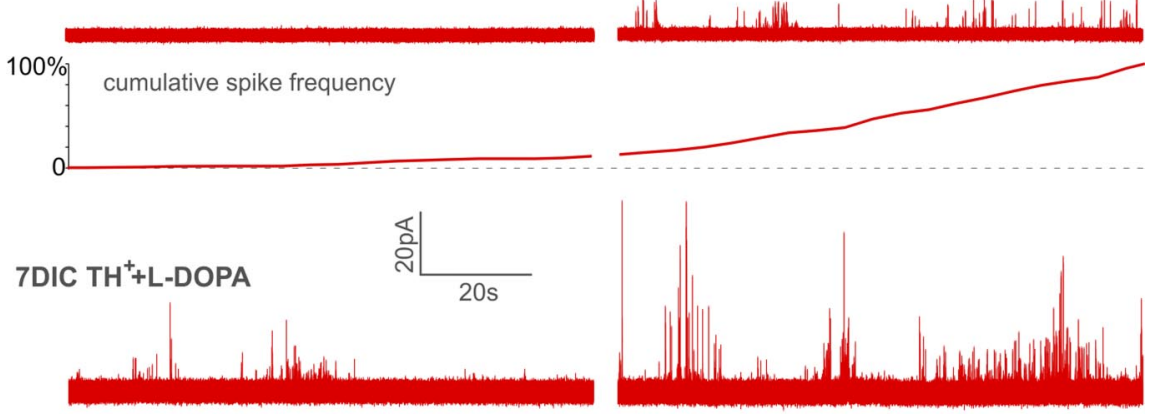

cumulative spike frequency

Figure 1. Amperometric detection of calcium-dependent vesicular dopamine release from $\mathrm{TH}^{+}$periglomerular cells. $\boldsymbol{A}$, Schematic drawing of the coronal section of a rodent brain shows A16 dopamine neurons (green) located in the glomerular layer of the olfactory bulb. $\mathrm{TH}^{+}$periglomerular neurons are apparent in a confocal image from a region (red square) of the glomerular layer in a TH-GFP mouse. Bottom panels, at 1 and 16 days in culture GFP-labeled putative dopamine neurons $\left(\mathrm{TH}^{+}\right.$) could be distinguished from other cells $\left(\mathrm{TH}^{-}\right.$) that were labeled by DAPI (blue). $\boldsymbol{B}$, Amperometric electrodes were calibrated by sustained puff of dopamine ( $3 \mu \mathrm{m}-5 \mathrm{~mm}$ ) from a perfusion pipette (right) onto the carbon fiber (top left). Dopamine perfusion elicited a dosedependent current on the carbon fiber electrode at a holding potential of $+700 \mathrm{mV}$ (right panels). The amperometric current was directly proportional the dopamine concentration with a detection threshold of $\leq 3 \mu \mathrm{m}$ (bottom left). C, Exemplary amperometric recordings before (left panels) and following whole-cell dialysis with a $20 \mu \mathrm{m} \mathrm{Ca}{ }^{2+}$-containing internal solution (right panels). The carbon fiber was gently pressed on the surface of a cell (black cylinder, top inset); the whole-cell patch pipette was positioned on the opposite side of the cell (top inset, right). Following the onset of whole-cell recording, $\mathrm{TH}^{+}$cells at either $1 \mathrm{DIC}$ (top panels) or $7 \mathrm{DIC}$ (middle panels) showed an increase in spike frequency, whereas $\mathrm{TH}^{-}$cells (bottom panels) had no amperometric spikes. $\mathrm{TH}^{+}$cells at $7 \mathrm{DIC}$ were preincubated with L-DOPA to enhance the sensitivity of the amperometric recording. Plots of the averaged cumulative spike frequency at 1 DIC (8 cells, 689 events) and 7 DIC (7 cells, 2536 events) confirm the increase in amperometric events during stimulation. Amperometric recording was begun $5 \mathrm{~s}$ after the onset of whole-cell dialysis.

Amperometry does not distinguish between oxidizable neurotransmitters such as dopamine, norepinephrine, and serotonin. Surprisingly, prior studies did not detect expression of the neuronal vesicular monoamine transporter VMAT2 in periglomerular cells (Peter et al. 1995; Weihe et al. 2006), raising a question as to whether dopamine was released from vesicles in these cells. Thus, we used real-time PCR (RT-PCR) to examine the dopaminergic phenotype of $\mathrm{TH}^{+}$periglomerular cells. RNA from fluorescence-activated cell sorting of $\mathrm{TH}^{+}$neurons (P21- 
Table 1. Real-Time PCR of TH ${ }^{+}$neurons sorted by flow cytometry

\begin{tabular}{lccc}
\hline Gene & \multicolumn{3}{c}{ mRNA $[\mathrm{ng}]$} \\
Tyrosine hydroxylase & $\mathbf{3 3 4} \pm \mathbf{4 1 . 3}$ & $0.2 \pm 0.05$ & $\mathbf{2 4 6 . 2} \pm \mathbf{1 2 . 9}$ \\
Dopamine $\beta$-hydroxylase & $0.03 \pm 0.02$ & ND & $\mathbf{2 2 6 . 5} \pm \mathbf{1 8 . 1}$ \\
VMAT1 & $0.03 \pm 0.02$ & $0.06 \pm 0.04$ & $\mathbf{3 0 1 . 8} \pm \mathbf{3 8 . 2}$ \\
VMAT2 & $\mathbf{1 6 4 . 7} \pm \mathbf{5 2 . 2}$ & $0.07 \pm 0.02$ & $\mathbf{1 8 6 . 3} \pm \mathbf{2 0 . 3}$ \\
NET & $0.02 \pm 0.002$ & $0.2 \pm 0.08$ & $\mathbf{3 2 7} \pm \mathbf{3 2 . 6}$ \\
DAT & $\mathbf{7 5 5 . 3} \pm \mathbf{1 7 5}$ & $12.7 \pm 1.38$ & $8.4 \pm 1.3$ \\
VGAT & $\mathbf{6 0 . 3} \pm \mathbf{3 . 7}$ & $0.02 \pm 0.01$ & $0.14 \pm 0.01$
\end{tabular}

FACS sorting of $\mathrm{TH}^{+}$periglomerular neurons showed that mRNAs necessary for dopamine synthesis (TH), storage (VMAT2), and reuptake (DAT) were present. However, dopamine- $\beta$-hydroxylase, necessary for norepinephrine synthesis, was not detected. HEK293 cell served as a negative control; chromaffin cells in adrenal glands showed the expected pattern for norepinephrine synthesis. Vesicular GABA transporter (VGAT) mRNA was present in $\mathrm{TH}^{+}$ periglomerular neurons, confirming a dual-neurotransmitter phenotype for $\mathrm{TH}^{+}$periglomerular cells. Data represent average of three different cell sorts. Values in bold type indicate the presence of RNA.
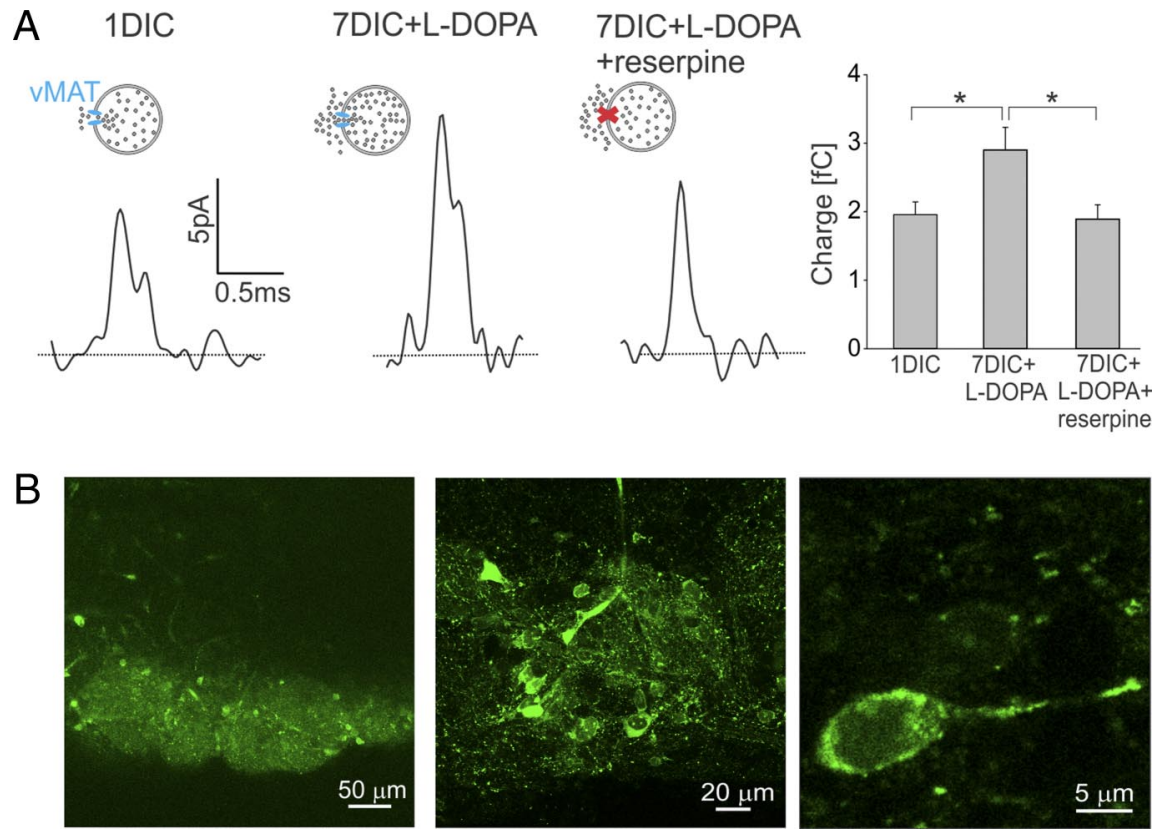

Figure 2. Quantal size of amperometric spikes was affected by L-DOPA and reserpine. $A$, Schematic representation of vesicles and corresponding exemplary amperometric spikes recorded at 1 DIC (left) following preincubation with L-DOPA (7 DIC, middle) and following incubation with L-DOPA and reserpine (7 DIC, right). At 7 DIC, the quantal charge of amperometric spikes increased dramatically following L-DOPA incubation (L-D0PA: 2628 spikes, 5 cells; control: 0 spikes, 5 cells), but this increase was reduced by subsequent L-D0PA/reserpine cotreatment (1868 spikes, 6 cells). The quantal size following reserpine was comparable to $\mathrm{TH}^{+}$cells at $1 \mathrm{DIC}(1180$ spikes, 8 cells). The histogram values represent the average of the median amperometric spike charge for each cell. $\boldsymbol{B}$, In vivo confocal imaging of acute olfactory bulb slices incubated with a fluorescent analog of dopamine revealed staining within glomerular cell layer, but not the external plexiform layer (left, $20 \times$, Z-projection of 11 images, $30 \mu \mathrm{m}$ depth). Athigher magnification, punctate staining was evident within each glomerulus (middle, $20 \times$,Z-projection of 11 images, $10 \mu \mathrm{m}$ depth) as well as in the soma and dendrites of individual cells (right, $63 \times$ ). Large, bright, linear structures represent staining within blood vessels.

28) was compared to that from HEK 293 and chromaffin cells (Table 1). In addition to tyrosine hydroxylase, $\mathrm{TH}^{+}$cells expressed VMAT2 and the plasma membrane dopamine transporter DAT, but not dopamine $\beta$-hydroxylase, which converts dopamine to norepinephrine. Consistent with functional dopamine uptake and release, incubation of $\mathrm{TH}^{+}$neurons with L-DOPA at 7 DIC had amperometric spikes with a charge of $2.9 \pm$ $0.3 \mathrm{fC}(n=5)$ that were larger than spikes from untreated cells at 1 DIC (Fig. $2 A, n=8$ ). Coincubation with the VMAT inhibitor reserpine $(1 \mu \mathrm{M}, 1 \mathrm{~h})$ prevented the L-DOPA-mediated increase in charge (reserpine: $1.9 \pm 0.2 \mathrm{fC}, n=6$ ). Reserpine treatment also decreased the amplitude and half-width of the spikes, consistent with reduced loading of the vesicles (data not shown). As expected from experiments with chromaffin cells (Gong et al.,
2003), reserpine strongly reduced but did not completely eliminate amperometric spikes following incubation for $1 \mathrm{~h}$ at $1 \mathrm{DIC}$ $(n=8$, not shown). Because the above data were performed in cells in culture, we confirmed that dopamine is also contained in vesicles in periglomerular neurons in intact tissue by incubating olfactory bulb slices with a fluorescent dopamine analog 12) and also showed a punctate staining pattern in PC12 and tent with the location of vesicles in both soma and dendrites of periglomerular cells in vivo (Pinching and Powell, 1971). Timelapse imaging revealed movement of puncta within labeled somas and dendrites (data not shown). These results indicate that $\mathrm{TH}^{+}$periglomerular cells have the molecular fingerprint of central dopamine neurons.

\section{Dopamine is released from small} clear vesicles

Dopamine can be released from either large dense core vesicles, LDCVs, or small clear vesicles (Bergquist and Ludwig, 2008). To determine the source of vesicular dopamine in periglomerular cells, we prepared electron micrographs of cultured $\mathrm{TH}^{+}$cells (Fig. 3A). Small clear vesicles (SCVs) were much more abundant than LDCVs (Fig. $3 B)$. LDCV s accounted for $<2 \%$ of the total vesicles. The vesicle size distribution was well described by a single Gaussian distribution with mean vesicle diameters of $49 \pm 8$ $\mathrm{nm}$ and $50 \pm 7 \mathrm{mn}$ for soma and dendrites, respectively (Fig. $3 C$ ), the expected size for SCVs. There were a few vesicles larger than $75 \mathrm{~nm}$, reflecting large dense core vesicles and unidentified vesicular structures. Consistent with dopamine release from small clear vesicles, amperometric spikes in $\mathrm{TH}^{+}$ periglomerular cells were much smaller than in chromaffin cells, which release monoamines from LDCVs (Fig. 3D). As with the vesicular size, the distribution of the cubic root of charge of amperometric spikes show a single peak that was reasonably fitted with a single Gaussian (Fig. 3C,E). Occasional larger events were likely double-release events. Thus, the morphological and functional data indicate that dopamine is released from a uniform population of vesicles.

\section{Release of dopamine and GABA follow distinct time courses} $\mathrm{TH}^{+}$neurons also contain GABAergic vesicles as we confirmed by staining of soma and dendrites with the vesicular GABA transporter VGAT (Fig. 4A). To assess release of GABA from periglomerular neurons, we used microisland cultures of single $\mathrm{TH}^{+}$periglomerular neurons (Tovar et al., 2009) that allowed stimulation and recording of synaptic release from a single neuron (autapse). A $500 \mu \mathrm{s}$ voltage step pulse from $-70 \mathrm{mV}$ to $+20 \mathrm{mV}$ triggered an unclamped action potential followed by the rapid onset of $\mathrm{GABA}_{\mathrm{A}}$-mediated IPSC that was completely blocked by SR95531 (Fig. 4B). Simultane- 


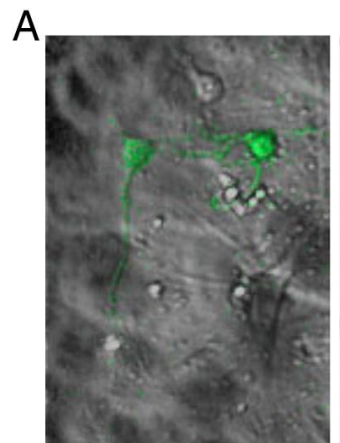

confocal microscopy in vitro

B
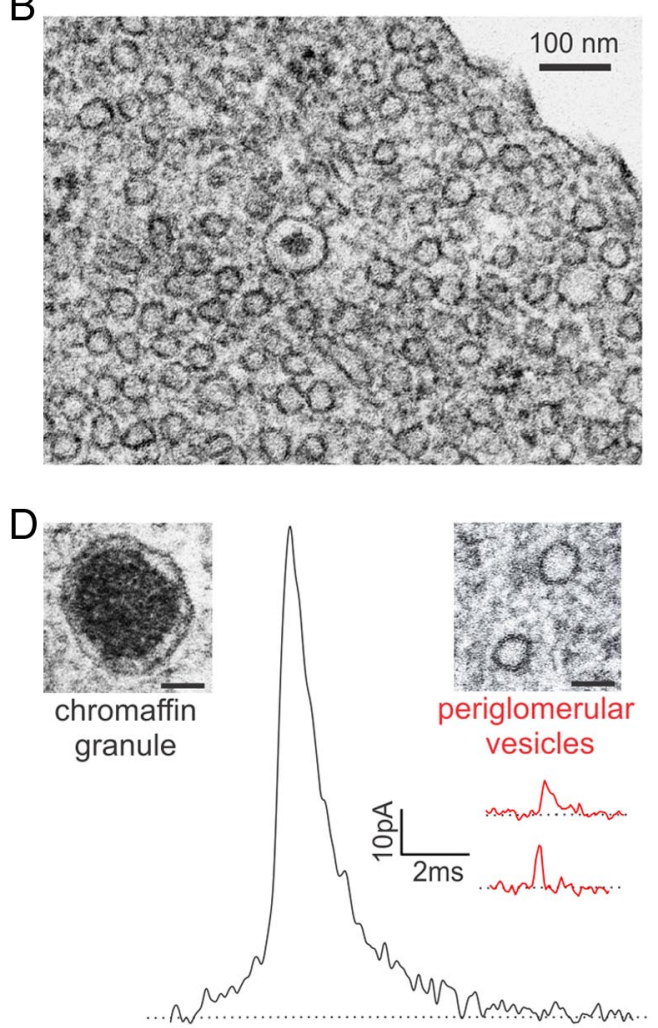

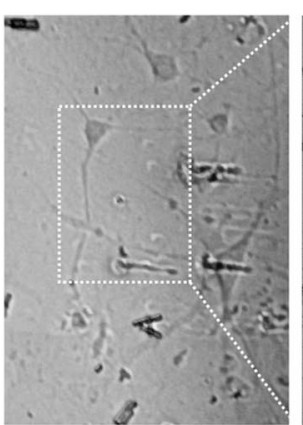

light microscopy of embedded cells

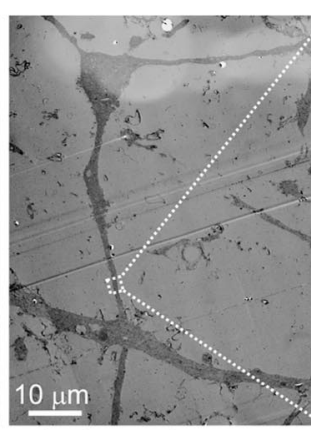

electron microscopy

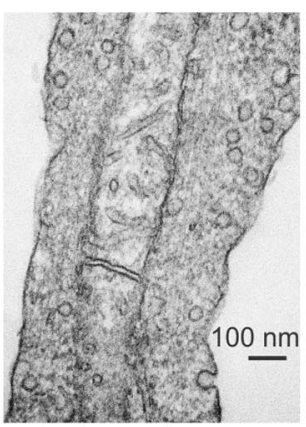

electron microscopy

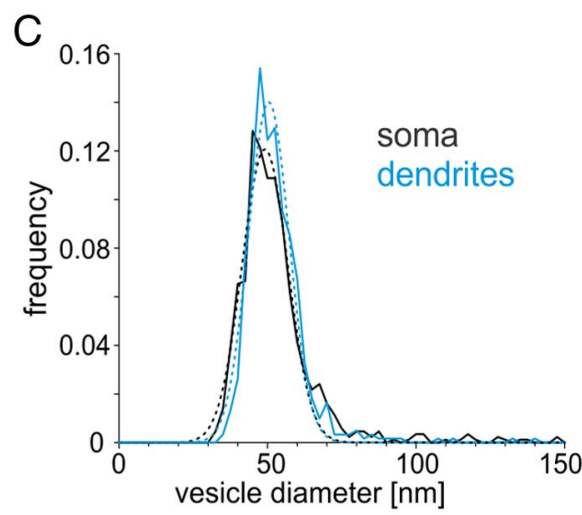

$\mathrm{E}$

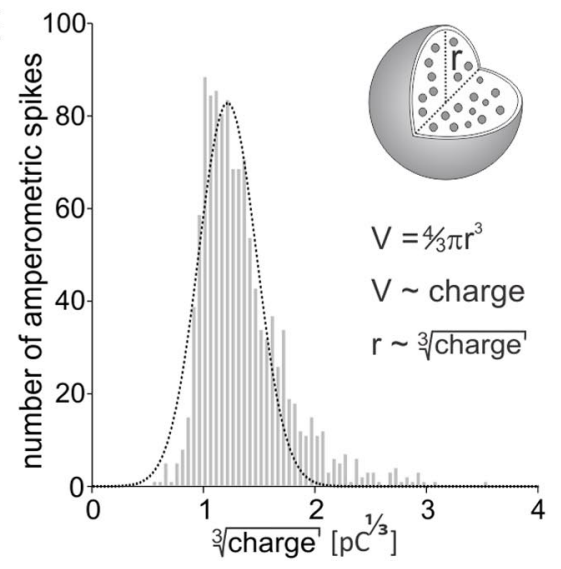

Figure 3. Electron microscopy of single $\mathrm{TH}^{+}$periglomerular cells. $A$, Individual $\mathrm{TH}^{+}$neurons in cell culture were identified with confocal microscopy for subsequent identification for electron microscopy as described in Materials and Methods. B, Electron micrographs of $\mathrm{TH}^{+}$periglomerular cells showed predominately small clear vesicles and occasional LDCVs. In the example shown, a single LDCV is present in this image from a $\mathrm{TH}^{+}$periglomerular cell soma. The LDCVs constituted $<2 \%$ of the total vesicles observed in images from 10 cells ( 29 LDCVs of 1484 total vesicles). C, The size of vesicles in the soma (black, $n=874$ from 11 cells) was the same as in dendrites (blue, $n=610$ from 5 cells). Gaussian fits gave mean vesicle diameters of $49 \pm 8 \mathrm{~nm}$ and $50 \pm 7 \mathrm{mn}$ for soma and dendrites, respectively. $\boldsymbol{D}$, Amperometric spikes recorded in a chromaffin cell (black trace) were much larger and longer-lasting that spikes recorded in periglomerular cell (red traces). The same recording methods were used for both cell types. Corresponding electron microscopy images of a chromaffin granule (left) and periglomerular dopamine neuron vesicles (right) also revealed the size difference between an LDCV in a chromaffin cell and the small clear vesicles in periglomerular cells. Scale, $50 \mathrm{~nm}$. $\boldsymbol{E}$, The distribution of the cubic root of charge (proportional to vesicle radius) was also consistent with a uniform vesicle population. The dotted line is a best fit to a single Gaussian. The threshold was set at $4 \mathrm{pA}$ (circa $3 \times$ RMS); thus, the left side of the distribution likely missed some small events, whereas the few larger events likely represent multivesicular release. Events recorded in $\mathrm{TH}^{+}$cells at $1 \mathrm{DIC}$ are shown.

ous amperometric recording of dopamine release and GABAmediated IPSCs showed a strikingly different time course of release. GABA release triggered a fast-rising IPSC that peaked within a few milliseconds and decayed within 50-100 ms, whereas there was not an immediate and easily apparent change in the frequency of amperometric spikes (Fig. 4C). However, as shown in Figure $4 D$, action potential stimulation did increase dopamine release as reflected in the increase in slope of the cumulative probability that began upon stimulation and continued for many seconds. The frequency of amperometric spikes (Figure $4 D$, red trace) increased by $86 \%$ following action potential stimulation ( $n=6, p=0.021$, paired $t$ test), demonstrating that physiological stimuli cause release of vesicular dopamine from these cells. As shown earlier in Figure 1, stimulation of these cells with step increases to high intracellular calcium caused a 4- to 20-fold increase, consistent with calcium dependence of dopamine release. Such a slow, persistent increase in amperometric dopamine spikes is similar to that observed by Jaffe et al. (1998) following exogenous glutamate stimulation in substantia nigra neurons. Although it is not possible to place a carbon fiber within a synaptic cleft, the difference in time course between synaptic GABA 
A

C

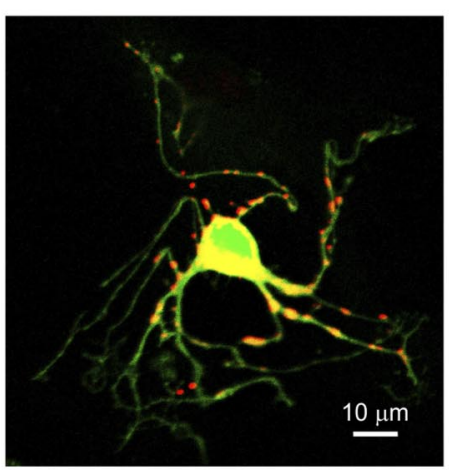

$90 \mathrm{mV}$

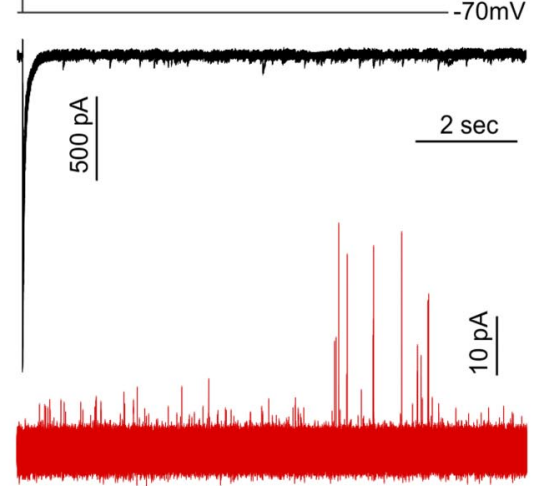

B

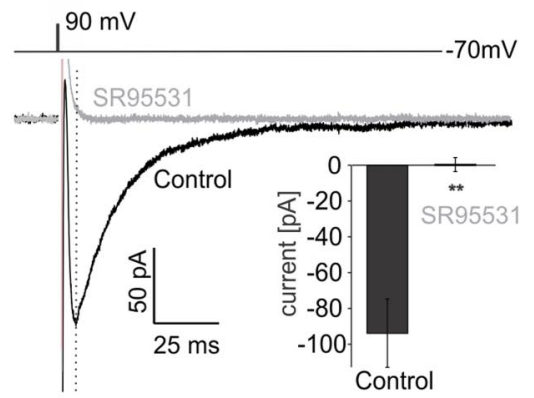

$\mathrm{D}$

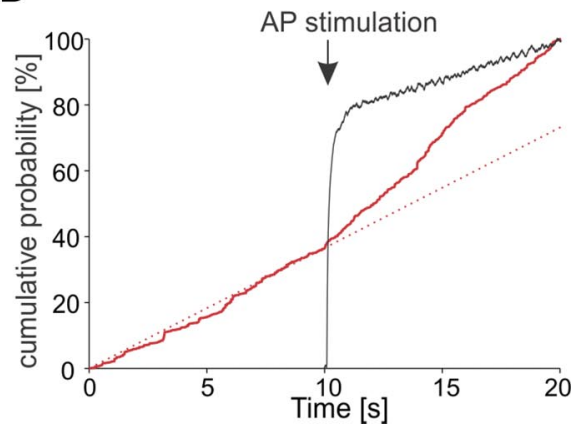

Figure 4. Simultaneous detection of $\mathrm{GABA}$ and dopamine release from $\mathrm{TH}^{+}$periglomerular cells. $\boldsymbol{A}$, Confocal image of periglomerular cells showed colocalization of $\mathrm{TH}^{+}$fluorescence (green) with the vesicular GABA transporter in the soma and dendrites (VGAT immunoreactivity, red). $\boldsymbol{B}, \mathrm{A}$ brief $(500 \mu \mathrm{s})$ depolarization (top) of a voltage-clamped $\mathrm{TH}^{+}$neuron $\left(\mathrm{V}_{\mathrm{h}}-70 \mathrm{mV}\right)$ in a microisland culture evoked a fast inhibitory postsynaptic current (black trace, average of 10 sweeps). The $\mathrm{GABA}_{\mathrm{A}}$ receptor antagonist SR95531 entirely blocked the IPSC (gray trace). Peak amplitudes measured at the peak (dashed line) are shown in the inset ( $n=5, p=0.005$, paired $t$ test). C, Simultaneous recording of a GABA -mediated IPSC (top trace, black, overlap of 10 sweeps) and dopamine (bottom trace, red, overlap of 10 sweeps) in a TH ${ }^{+}$cell. The GABA-mediated IPSC reached a peak within a few milliseconds after depolarization, whereas there was not an abrupt increase in the frequency of amperometricspikes. Rather, the rate of asynchronous release increased from the baseline and remained increased formanyseconds. $D$, The GABA current and amperometric event frequency were normalized and plotted as a cumulative probability for all cells recorded with the protocol shown in C. As expected, the vast majority of GABA release (black line, average of eight cells) occurred immediately following action potential (AP) stimulation (arrow). The pattern for dopamine release was much different. As shown by the positive slope of the solid red line before stimulation, there were ongoing spontaneous amperometric events (red line). Stimulation caused an increase in spike frequency that persisted for seconds, as indicated by the change in the slope (red line, average of 6 cells). The bin size for amperometric spikes was 10 ms and total spikes $=1431$. The extrapolated rate of spontaneous amperometric spikes is shown in the dotted line.

release and somatodendritic dopamine release suggests that the release mechanisms are distinct. Consistent with this idea, application of sucrose $(500 \mathrm{mM})$, which releases primed vesicles (Rosenmund and Stevens, 1996), evoked a barrage of GABA-mediated IPSCs, but no amperometric spikes ( $n=16$, data not shown).

\section{Discussion}

\section{Somatodendritic release of dopamine originates from small} clear vesicles

Our results demonstrate that $\mathrm{TH}^{+}$periglomerular neurons are functional dual transmitter neurons that release both dopamine and GABA. The charge associated with each amperometric spike predicts that $\sim 6000$ dopamine molecules are released per fusion, much less than expected for large dense core vesicles. Our estimates correspond to a concentration of $160 \mathrm{~mm}$ for $50 \mathrm{~nm}$ small clear vesicles. L-DOPA preincubation increased the quantal size to about 9000 molecules. These estimates agree well with amperometry of L-DOPA-treated cultured ventral midbrain neurons and leech serotonin neurons, but are substantially less than expected if release occurred from large dense core vesicles (Bruns and Jahn, 1995; Staal et al., 2004). Our estimate for vesicular dopamine concentration in small clear vesicles is similar to the amino acid transmitter concentration in synaptic vesicles (Burger et al., 1989). To efficiently sample vesicular release of dopamine, we placed the carbon fiber against the somatic membrane to maximize the surface area exposure. Although amperometry does not allow direct detection of release within a synaptic cleft, we were able to detect occasional amperometric spikes from small dendritic varicosities. Our results are consistent with the focal dendritic release of high concentrations of dopamine in the ventral tegmental area (Ford et al., 2009). Each glomerulus is highly compartmentalized (Kasowski et al., 1999), and thus dopamine signaling may be segregated between dendrodendritic and axodendritic compartments to modulate dendrodendritic synapses and olfactory nerve terminals, respectively (Murphy et al., 2005; Maher and Westbrook, 2008). Furthermore, $\mathrm{TH}^{+}$cells can contact multiple glomeruli (Kiyokage et al., 2010), and it is also possible that dopamine mediates interglomerular signaling.

\section{The functional dual} transmitter phenotype

Although dual transmitter neurons containing dopamine and either glutamate or GABA occur in multiple brain regions (Hnasko and Edwards, 2012), the spatiotemporal characteristics of their (co)release is only beginning to be explored (Chuhma et al., 2004; Onoa et al., 2010). In our experiments, GABA release followed a classical fast release pattern, whereas dopamine release increased gradually for many seconds following stimulation with either high intracellular calcium or single action potentials. GABA release can occur asynchronously following action potential stimulation, but this usually lasts $<1 \mathrm{~s}$ (Hefft and Jonas, 2005). The long-lasting, asynchronous amperometric response could conceivably reflect the extrasynaptic location of the carbon fiber electrode. However, dopamine release was increased by intracellular calcium and by action potential stimulation, indicating that the stimuli reached dopamine release sites. Unlike GABA, dopamine release was also not triggered by sucrose, which triggers the readily releasable pool of vesicles. It thus seems likely that the molecular determinants of release differ between DA- and GABA-containing vesicles. For example, synaptotagmin 1 likely mediates synchronous GABA release in $\mathrm{TH}^{+}$periglomerular neurons, whereas other synaptotagmin isoforms may mediate dopamine release (Mittelsteadt et al., 2009; Pang and Sudhof, 2010). Dopamine release might also require different stimulus conditions, such as release of calcium from intracellular stores (Tse et al., 1997). Our results indicate that $\mathrm{TH}^{+}$cells in the glomerulus are remarkably multifunctional. The release of two neurotransmitters with distinct spatiotemporal profiles may allow these cells to control synaptic timing in both intraglomerular and interglomerular circuits. 


\section{References}

Aroniadou-Anderjaska V, Zhou FM, Priest CA, Ennis M, Shipley MT (2000) Tonic and synaptically evoked presynaptic inhibition of sensory input to the rat olfactory bulb via $\mathrm{GABA}_{\mathrm{B}}$ heteroreceptors. J Neurophysiol 84:1194-1203. Medline

Bergquist F, Ludwig M (2008) Dendritic transmitter release: a comparison of two model systems. J Neuroendocrinol 20:677-686. CrossRef Medline

Borisovska M, Zhao Y, Tsytsyura Y, Glyvuk N, Takamori S, Matti U, Rettig J, Südhof T, Bruns D (2005) v-SNAREs control exocytosis of vesicles from priming to fusion. EMBO J 24:2114-2126. CrossRef Medline

Borisovska M, McGinley MJ, Bensen A, Westbrook GL (2011) Loss of olfactory cell adhesion molecule reduces the synchrony of mitral cell activity in olfactory glomeruli. J Physiol 589:1927-1941. CrossRef Medline

Bruns D (2004) Detection of transmitter release with carbon fiber electrodes. Methods 33:312-321. CrossRef Medline

Bruns D, Jahn R (1995) Real-time measurement of transmitter release from single synaptic vesicles. Nature 377:62-65. CrossRef Medline

Burger PM, Mehl E, Cameron PL, Maycox PR, Baumert M, Lottspeich F, De Camilli P, Jahn R (1989) Synaptic vesicles immunoisolated from rat cerebral cortex contain high levels of glutamate. Neuron 3:715-720. CrossRef Medline

Chuhma N, Zhang H, Masson J, Zhuang X, Sulzer D, Hen R, Rayport S (2004) Dopamine neurons mediate a fast excitatory signal via their glutamatergic synapses. J Neurosci 24:972-981. CrossRef Medline

Coopersmith R, Weihmuller FB, Kirstein CL, Marshall JF, Leon M (1991) Extracellular dopamine increases in the neonatal olfactory bulb during odor preference training. Brain Res 564:149-153. CrossRef Medline

Coronas V, Srivastava LK, Liang JJ, Jourdan F, Moyse E (1997) Identification and localization of dopamine receptor subtypes in rat olfactory mucosa and bulb: a combined in situ hybridization and ligand binding radioautographic approach. J Chem Neuroanat 12:243-257. CrossRef Medline

Cragg SJ, Nicholson C, Kume-Kick J, Tao L, Rice ME (2001) Dopaminemediated volume transmission in midbrain is regulated by distinct extracellular geometry and uptake. J Neurophysiol 85:1761-1771. Medline

Dahlström A, Fuxe K (1964) Localization of monoamines in the lower brain stem. Experientia 20:398-399. CrossRef Medline

Doty RL (2012) Olfaction in Parkinson's disease and related disorders. Neurobiol Dis 46:527-552. CrossRef Medline

Ennis M, Zhou FM, Ciombor KJ, Aroniadou-Anderjaska V, Hayar A, Borrelli E, Zimmer LA, Margolis F, Shipley MT (2001) Dopamine D2 receptormediated presynaptic inhibition of olfactory nerve terminals. J Neurophysiol 86:2986-2997. Medline

Ford CP, Phillips PEM, Williams JT (2009) The time course of dopamine transmission in the ventral tegmental area. J Neurosci 29:13344-13352. CrossRef Medline

Gong LW, Hafez I, Alvarez de Toledo G, Lindau M (2003) Secretory vesicles membrane area is regulated in tandem with quantal size in chromaffin cells. J Neurosci 23:7917-7921. Medline

Halász N, Hökfelt T, Ljungdahl A, Johansson O, Goldstein M (1977) Dopamine neurons in the olfactory bulb. Adv Biochem Psychopharmacol 16:169-177. Medline

Hannah MJ, Weiss U, Huttner WB (1998) Differential extraction of proteins from paraformaldehyde-fixed cells: lessons from synaptophysin and other membrane proteins. Methods 16:170-181. CrossRef Medline

Hefft S, Jonas P (2005) Asynchronous GABA release generates long-lasting inhibition at a hippocampal interneuron-principal neuron synapse. Nat Neurosci 8:1319-1328. CrossRef Medline

Hnasko TS, Edwards RH (2012) Neurotransmitter corelease: mechanism and physiological role. Annu Rev Physiol 74:225-243. CrossRef Medline

Hsia AY, Vincent JD, Lledo PM (1999) Dopamine depresses synaptic inputs into the olfactory bulb. J Neurophysiol 82:1082-1085. Medline

Jaffe EH, Marty A, Schulte A, Chow RH (1998) Extrasynaptic vesicular transmitter release from the somata of substantia nigra neurons in rat midbrain slices. J Neurosci 18:3548-3553. Medline

Kasowski HJ, Kim H, Greer CA (1999) Compartmental organization of the olfactory bulb glomerulus. J Comp Neurol 407:261-274. CrossRef Medline

Kiyokage E, Pan YZ, Shao Z, Kobayashi K, Szabo G, Yanagawa Y, Obata K, Okano H, Toida K, Puche AC, Shipley MT (2010) Molecular identity of periglomerular and short axon cells. J Neurosci 30:1185-1196. CrossRef Medline
Leszczyszyn DJ, Jankowski JA, Viveros OH, Diliberto EJ Jr, Near JA, Wightman RM (1990) Nicotinic receptor-mediated catecholamine secretion from individual chromaffin cells: chemical evidence for exocytosis. J Biol Chem 265:14736-14737. Medline

Maher BJ, Westbrook GL (2008) Co-transmission of dopamine and GABA in periglomerular cells. J Neurophysiol 99:1559-1564. CrossRef Medline Masurovsky EB, Bunge RP (1968) Fluoroplastic coverslips for long-term nerve tissue culture. Stain Technol 43:161-165. Medline

Mittelsteadt T, Seifert G, Alvárez-Barón E, Steinhäuser C, Becker AJ, Schoch $S$ (2009) Differential mRNA expression patterns of the synaptotagmin gene family in the rodent brain. J Comp Neurol 512:514-528. CrossRef Medline

Murphy GJ, Darcy DP, Isaacson JS (2005) Intraglomerular inhibition: signaling mechanisms of an olfactory microcircuit. Nat Neurosci 8:354-364. CrossRef Medline

Onoa B, Li H, Gagnon-Bartsch JA, Elias LAB, Edwards RH (2010) Vesicular monoamine and glutamate transporters select distinct synaptic vesicle recycling pathways. J Neurosci 30:7917-7927. CrossRef Medline

Pang ZP, Südhof TC (2010) Cell biology of $\mathrm{Ca}^{2+}$-triggered exocytosis. Curr Opin Cell Biol 22:496-505. CrossRef Medline

Parker LK, Shanks JA, Kennard JA, Brain KL (2010) Dynamic monitoring of NET activity in mature murine sympathetic terminals using a fluorescent substrate. Br J Pharmacol 159:797-807. CrossRef Medline

Parrish-Aungst S, Shipley MT, Erdelyi F, Szabo G, Puche AC (2007) Quantitative analysis of neuronal diversity in the mouse olfactory bulb. J Comp Neurol 501:825-836. CrossRef Medline

Parsons TD, Coorssen JR, Horstmann H, Almers W (1995) Docked granules, the exocytic burst, and the need for ATP hydrolysis in endocrine cells. Neuron 15:1085-1096. CrossRef Medline

Peter D, Liu Y, Sternini C, de Giorgio R, Brecha N, Edwards RH (1995) Differential expression of two vesicular monoamine transporters. J Neurosci 15:6179-6188. Medline

Pinching AJ, Powell TPS (1971) The neuron types of the glomerular layer of the olfactory bulb. J Cell Sci 9:305-345. Medline

Pothos EN, Davila V, Sulzer D (1998) Presynaptic recording of quanta from midbrain dopamine neurons and modulation of the quantal size. J Neurosci 18:4106-4118. Medline

Pothos E, Desmond M, Sulzer D (1996) 1-3,4-Dihydroxyphenylalanine increases the quantal size of exocytotic dopamine release in vitro. J Neurochem 66:629-636. CrossRef Medline

Puopolo M, Hochstetler SE, Gustincich S, Wightman RM, Raviola E (2001) Extrasynaptic release of dopamine in a retinal neuron: activity dependence and transmitter modulation. Neuron 30:211-225. CrossRef Medline

Rosenmund C, Stevens CF (1996) Definition of the readily releasable pool of vesicles at hippocampal synapses. Neuron 16:1197-1207. CrossRef Medline

Sawamoto K, Nakao N, Kobayashi K, Matsushita N, Takahashi H, Kakishita K, Yamamoto A, Yoshizaki T, Terashima T, Murakami F, Itakura T, Okano H (2001) Visualization, direct isolation, and transplantation of midbrain dopaminergic neurons. Proc Natl Acad Sci U S A 98:6423-6428. CrossRef Medline

Smith TC, Jahr CE (2002) Self-inhibition of olfactory bulb neurons. Nat Neurosci 5:760-766. CrossRef Medline

Staal RGW, Mosharov EV, Sulzer D (2004) Dopamine neurons release transmitter via a flickering fusion pore. Nature Neuroscience 7:341-346. CrossRef Medline

Taylor TN, Caudle WM, Shepherd KR, Noorian A, Jackson CR, Iuvone PM, Weinshenker D, Greene JG, Miller GW (2009) Non-motor symptoms of Parkinson's disease revealed in an animal model with reduced monoamine storage capacity. J Neurosci 29:8103-8113. CrossRef Medline

Tillerson JL, Caudle WM, Parent JM, Gong C, Schallert T, Miller GW (2006) Olfactory discrimination deficits in mice lacking the dopamine transporter or the D2 dopamine receptor. Behav Brain Res 172:97-105. CrossRef Medline

Toida K, Kosaka K, Aika Y, Kosaka T (2000) Chemically defined neuron groups and their subpopulations in the glomerular layer of the rat main olfactory bulb-IV. Intraglomerular synapses of tyrosine hydroxylaseimmunoreactive neurons. Neuroscience 101:11-17. CrossRef Medline

Tovar KR, Maher BJ, Westbrook GL (2009) Direct actions of carbenoxolone on synaptic transmission and neuronal membrane properties. J Neurophysiol 102:974-978. CrossRef Medline 
Tse FW, Tse A, Hille B, Horstmann H, Almers W (1997) Local Ca ${ }^{2+}$ release from internal stores controls exocytosis in pituitary gonadotrophs. Neuron 18:121132. CrossRef Medline

Weihe E, Depboylu C, Schütz B, Schäfer M, Eiden L (2006) Three types of tyrosine hydroxylase-positive CNS neurons distinguished by DOPA decarboxylase and VMAT2 Co-expression. Cell Mol Neurobiol 26:657-676. CrossRef
Wightman RM, Jankowski JA, Kennedy RT, Kawagoe KT, Schroeder TJ, Leszczyszyn DJ, Near JA, Diliberto EJ Jr, Viveros OH (1991) Temporally resolved catecholamine spikes correspond to single vesicle release from individual chromaffin cells. Proc Natl Acad Sci U S A 88:10754-10758. CrossRef Medline 